Karolina Stawnicka-Kowalczyk

Uniwersytet Marii Curie-Skłodowskiej w Lublinie

ORCID: https://orcid.org/0000-0003-2741-6375

karolina.stawnicka@gmail.com

\title{
Analiza danych osobowych przetwarzanych przez apteki w kontekście zmian wprowadzonych przez ogólne rozporządzenie o ochronie danych osobowych
}

\author{
Analysis of Personal Data Processing by Pharmacies in the \\ Context of Changes Resulting from the General Data Protection \\ Regulation
}

\section{STRESZCZENIE}

Niniejsze opracowanie dotyczy problematyki przetwarzania danych osobowych w aptece ogólnodostępnej. Autorka dokonuje analizy danych osobowych przetwarzanych przez apteki w oparciu o przepisy ogólnego rozporządzenia o ochronie danych osobowych. Analizie zostały poddane dane osobowe, których przetwarzanie jest nierozerwalnie związane z działalnością apteki. Autorka szczególną uwagę skupiła na tzw. danych szczególnych przetwarzanych przez apteki, głównie w kontekście dopuszczalności ich przetwarzania.

Słowa kluczowe: dane osobowe; prawo farmaceutyczne; apteka; RODO; rozporządzenie o ochronie danych osobowych; dane szczególne; dane wrażliwe

\section{WSTĘP}

W dniu 14 kwietnia 2016 r. Parlament Europejski przyjął ogólne rozporządzenie o ochronie danych osobowych ${ }^{1}$, zastępujące obowiązującą dyrektywę 95/46/WE Parlamentu Europejskiego i Rady z dnia 24 października 1995 r. w sprawie ochro-

1 Rozporządzenie Parlamentu Europejskiego i Rady (UE) 2016/679 z dnia 27 kwietnia 2016 r. w sprawie ochrony osób fizycznych w związku z przetwarzaniem danych osobowych i w sprawie 
ny osób fizycznych w zakresie przetwarzania danych osobowych i swobodnego przepływu tych danych ${ }^{2}$. Zgodnie z komunikatem Komisji do Parlamentu Europejskiego i Rady wprowadzającym projekty przedmiotowe rozporządzenie ma zapewniać solidne i spójne ramy prawne dotyczące wszystkich obszarów polityki UE, wzmacniając prawa osób fizycznych oraz wymiar jednolitego rynku dotyczącego ochrony danych osobowych. Ponadto wprowadzenie powyższych rozwiązań ma ograniczyć obciążenia administracyjne dla przedsiębiorców³ ${ }^{3}$ Od 25 maja $2018 \mathrm{r}$. RODO jest stosowane we wszystkich państwach członkowskich w sposób bezpośredni, a obowiązująca od ponad 20 lat dyrektywa 95/46/WE została usunięta z porządku prawnego. Data ta stanowi swoistą cezurę w rozwoju prawa ochrony danych osobowych, ponieważ dotychczasowy obraz ram prawnych ochrony danych osobowych uległ radykalnej zmianie ${ }^{4}$.

RODO budzi szereg kontrowersji i wątpliwości. Unijny prawodawca wprowadził wiele nowych rozwiązań, co rodzi potrzebę wyznaczenia nowych wzorców postępowania. Przede wszystkim na gruncie nowych przepisów brak dotychczas obowiązujących sztywnych wytycznych. RODO w rzeczywistości stawia przedsiębiorcom cel, który powinni osiągnąć, jednocześnie nie wskazując dokładnej drogi do niego. Na szereg pytań powstających na gruncie stosowania RODO przedsiębiorca musi odpowiedzieć sam, posiłkując się analizą ryzyka przetwarzania danych osobowych w swojej organizacji, a także dokonując analizy wykorzystywanych rozwiązań organizacyjnych i technologicznych. Prawodawca unijny starał się stworzyć rozporządzenie neutralne zarówno organizacyjnie, jak i technologicznie - takie rozwiązanie ma zapewnić przedsiębiorcom dowolność w zakresie rozwiązań mających zagwarantować bezpieczeństwo przetwarzanych danych osobowych. W zamyśle takie rozwiązanie ma dać również dłuższe życie przedmiotowemu aktowi prawnemu i uchronić go przed zbyt szybką dezaktualizacją w związku z postępującym rozwojem, zwłaszcza technicznym. Przyjęcie takiego rozwiązania nasuwa szereg wątpliwości co do tego, w jaki sposób wdrożyć RODO w poszczególnych organizacjach.

swobodnego przepływu takich danych oraz uchylenia dyrektywy 95/46/WE (ogólne rozporządzenie o ochronie danych) (Dz.Urz. UE L z 2016 r., nr 119, s. 1 z późn. zm.), dalej jako: RODO.

2 Dyrektywa 95/46/WE Parlamentu Europejskiego i Rady z dnia 24 października 1995 r. w sprawie ochrony osób fizycznych w zakresie przetwarzania danych osobowych i swobodnego przepływu tych danych (Dz.Urz. UE L 281, 23.11.1995, P. 0031-0050). Zob. Ogólne rozporządzenie o ochronie danych osobowych. Wybrane zagadnienia, red. M. Kawecki, T. Osiej, Warszawa 2017, s. 1.

3 Komunikat Komisji do Parlamentu Europejskiego, Rady Europejskiej, Komitetu Ekonomiczno-Społecznego i Komitetu Regionów: Ochrona prywatności w połączonym świecie - europejskie ramy ochrony danych w XXI wieku, COM (2012) 9 final, s. 4 (EUR-Lex - 52012DC0009 - EN).

4 E. Bielak-Jomaa, D. Lubasz, Stowo wstępne, [w:] RODO. Ogólne rozporządzenie o ochronie danych. Komentarz, red. E. Bielak-Jomaa, D. Lubasz, Warszawa 2018. 
Problematyka stosowania RODO z całą pewnością nie pozostanie obojętna dla obrotu produktami leczniczymi. Przez obrót produktami leczniczymi należy rozumieć „każdą postać przeniesienia własności produktu leczniczego, w tym pod tytułem darmym w obrębie obrotu cywilnoprawnego i na mocy czynności prawnej"5. Ustawa Prawo farmaceutyczne ${ }^{6}$ rozróżnia hurtowy i detaliczny obrót produktami leczniczymi, nie definiując jednak tych pojęć. W niniejszym opracowaniu rozważania zostaną ograniczone do obrotu detalicznego, który prowadzą apteki ogólnodostępne, punkty apteczne oraz placówki obrotu pozaaptecznego ${ }^{7}$. Zgodnie z art. 86 ust. 1 ustawy Prawo farmaceutyczne apteka jest placówką ochrony zdrowia publicznego, w której osoby uprawnione świadczą w szczególności usługi farmaceutyczne. W tym miejscu należy wskazać, że określenie „placówka”, użyte $\mathrm{w}$ ustawie, zaczerpnięte z języka potocznego, powinno być traktowane jako przedsiębiorstwo w rozumieniu art. $55^{1}$ Kodeksu cywilnego ${ }^{8}$. Z wymienionych powyżej form detalicznego obrotu produktami leczniczymi za najbardziej modelowy i posiadający najszersze kompetencje w zakresie rozpowszechniania produktów leczniczych należy uznać aptekę ogólnodostępną, która będzie stanowić główny odnośnik do analizy przepisów RODO w niniejszym opracowaniu.

Przed przejściem do szczegółowych zagadnień warto określić, na kogo w głównej mierze scedowany jest obowiązek wdrożenia przepisów RODO w aptekach ogólnodostępnych, a mianowicie pochylić się nad pojęciem administratora. Zgodnie z art. 4 pkt 7 RODO administrator to osoba fizyczna lub prawna, jednostka lub inny podmiot, który samodzielnie lub wspólnie z innymi osobami ustala cele i sposoby przetwarzania danych osobowych. W aptece ogólnodostępnej administratorem w rozumieniu RODO będzie podmiot prowadzący aptekę ogólnodostępną. Administratorem danych nie będzie więc kierownik apteki czy zatrudnieni w niej farmaceuci i technicy farmaceutyczni.

Pojęcie administratora ma istotne znaczenie, ponieważ to administrator jest adresatem szeregu obowiązków wynikających z RODO - odpowiada za zgodność przetwarzania danych z określonymi zasadami i ponosi pełną odpowiedzialność za przetwarzanie danych, prowadzi je samodzielnie lub jest ono prowadzone w jego imieniu?

5 L. Ogiełło, Prawo farmaceutyczne. Komentarz, Warszawa 2010, s. 649.

6 Ustawa z dnia 6 września 2001 r. - Prawo farmaceutyczne (Dz.U. z 2017 r., poz. 2211).

7 Meritum Prawo Farmaceutyczne, red. B. Wawrzyńczak-Jędryka, Warszawa 2016, s. 24.

8 Ustawa z dnia 23 kwietnia 1964 r. - Kodeks cywilny (Dz.U. z 2017 r., poz. 459 z późn. zm.); M. Kwiatkowska, Prawo farmaceutyczne dla aptek, cz. 1, Warszawa 2017, s. 24-25.

9 D. Lubasz, W. Chomiczewski, M. Czerniawski, P. Drobek, U. Góral, M. Kuba, P. Makowski, K. Witkowska-Nowakowska, Art. 4, [w:] RODO. Ogólne rozporządzenie o ochronie danych... 


\section{DANE OSOBOWE PRZETWARZANE PRZEZ APTEKI W RAMACH WYKONYWANIA OPIEKI FARMACEUTYCZNEJ}

Co do zasady świadczenie usług przez apteki kojarzy się ze sprzedażą przez farmaceutę produktów leczniczych pacjentom. Choć dla większości aptek ogólnodostępnych stanowi to główny i podstawowy przedmiot działalności, to uznanie, że sprzedaż produktów leczniczych wyczerpuje pojęcie usługi farmaceutycznej, jest jak najbardziej błędne ${ }^{10}$. Przede wszystkim w kontekście danych gromadzonych przez aptekę i wpływu RODO na jej działalność warto rozpatrzyć zagadnienie opieki farmaceutycznej, polegającej na dokumentowanym procesie, w którym farmaceuta, współpracując z pacjentem i lekarzem, a w razie potrzeby z przedstawicielami innych zawodów, czuwa nad prawidłowym przebiegiem farmakoterapii w celu uzyskania określonych jej efektów poprawiających jakość życia pacjenta (art. 2a ust. 1 pkt 7 ustawy o izbach aptekarskich ${ }^{11}$ ). W Polsce świadczenie opieki farmaceutycznej nie jest powszechne i tego typu opieka sprawowana jest przede wszystkim przez farmaceutów klinicznych działających w aptekach szpitalnych ${ }^{12}$. Nie oznacza to jednak, że obecnie w ogóle nie spotykamy się z opieką farmaceutyczną w aptekach ogólnodostępnych. Mamy bowiem do czynienia z realizowaniem przez apteki określonych programów opieki farmaceutycznej, mimo że brak stosownych ram prawnych znacznie utrudnia wskazaną działalność aptek i rodzi szerokie problemy interpretacyjne. Bardzo często apteki, prowadząc określone programy opieki farmaceutycznej, spotykają się z zarzutem, iż stanowi ona pretekst do działalności o charakterze reklamowym i zachęcającym (reklamowanie aptek jest zakazane $)^{13}$. Obecnie w Sejmie trwają prace nad dokładnym uregulowaniem i wdrożeniem w aptekach w sposób bardziej kompleksowy opieki farmaceutycznej w związku z przygotowywaną ustawą o zawodzie farmaceuty. Należy w tym zakresie spodziewać się istotnych zmian, które być może doprowadzą do spopularyzowania opieki farmaceutycznej w Polsce. Niemniej już na ten moment część aptek wprowadza do swojej działalności różnego rodzaju programy opieki farmaceutycznej, a dane gromadzone w związku z ich realizacją z całą pewnością nie są obojętne dla unijnej reformy ochrony danych osobowych.

Opieka farmaceutyczna w głównej mierze opiera się na podejmowaniu przez farmaceutę takich czynności, jak: gromadzenie danych o wszystkich lekach zażywanych przez pacjenta, a przy tym informowanie go o możliwych interakcjach

10 M. Ożóg, System handlu produktem leczniczym i produktami pokrewnymi. Problematyka prawna, Warszawa 2010, s. 358.

11 Ustawa z dnia 19 kwietnia 1991 r. o izbach aptekarskich (Dz.U. z 2016 r., poz. 1496).

12 J. Masiakowski, Farmaceuta kliniczny jako producent i dystrybutor leków oraz konsultant w zespole opieki nad chorym, [w:] Zarys farmacji klinicznej, red. L. Krówczyński, A. Danek, Warszawa 1988, s. 20-25.

13 Zob. wyrok NSA z dnia 27 sierpnia 2014 r., II GSK 1000/13, LEX nr 1527483. 
lekowych i o ubocznym działaniu leków; ustalanie dla pacjenta różnego rodzaju diet; interpretacja wyników badań laboratoryjnych, a przy tym gromadzenie wyników tych badań; zbieranie informacji na podstawie kart leczenia pacjenta, a także danych istotnych dla świadczenia opieki farmaceutycznej, np. dotyczących uzależnień od alkoholu, tytoniu czy narkotyków. Zgodnie z art. 4 pkt 1 ogólnego rozporządzenia za dane osobowe należy uznać informacje o zidentyfikowanej lub możliwej do zidentyfikowania osobie fizycznej, a możliwa do zidentyfikowania osoba fizyczna to taka, którą można bezpośrednio lub pośrednio zidentyfikować, w szczególności na podstawie identyfikatora, takiego jak imię i nazwisko, numer identyfikacyjny, dane o lokalizacji, identyfikator internetowy lub jeden bądź kilka szczególnych czynników określających fizyczną, fizjologiczną, genetyczną, psychiczną, ekonomiczną, kulturową lub społeczną tożsamość osoby fizycznej. Ponadto RODO rozróżnia tzw. dane szczególne (na gruncie poprzednich przepisów są to tzw. dane wrażliwe), do których należą m.in. dane dotyczące zdrowia. Zgodnie z 35 motywem ogólnego rozporządzenia:

[...] do danych osobowych dotyczących zdrowia należy zaliczyć wszystkie dane o stanie zdrowia osoby, której dane dotyczą, ujawniające informację o przeszłym, obecnym lub przyszłym stanie fizycznego lub psychicznego zdrowia osoby, której dane dotyczą. Do danych takich należą informacje o danej osobie fizycznej zbierane podczas jej rejestracji do usług opieki zdrowotnej lub podczas świadczenia jej usług opieki zdrowotnej, jak to określa dyrektywa Parlamentu Europejskiego i Rady 2011/24/UE numer, symbol lub oznaczenie przypisane danej osobie fizycznej do celów zdrowotnych, informacje pochodzące z badań laboratoryjnych lub lekarskich części ciał lub płynów ustrojowych, w tym danych genetycznych i próbek biologicznych oraz wszelkie informacje, np. o chorobie, niepełnosprawności, ryzyku choroby, historii medycznej, leczeniu klinicznym lub stanie fizjologicznym lub biomedycznym osoby, której dane dotyczą, niezależnie od ich źródła, którym może być np. lekarz lub inny pracownik służby zdrowia, szpital, urządzenie medyczne lub badanie diagnostyczne in vitro ${ }^{14}$.

Co do zasady przetwarzanie danych dotyczących zdrowia jest zabronione. W ogólnym rozporządzeniu został zamieszczony zamknięty katalog wyłączający powyższy zakaz. Dla działalności apteki w tym zakresie najistotniejsze znaczenie będą miały dwa wyłączenia: 1) wyraźna zgoda osoby, której dane dotyczą oraz 2) sytuacja, gdy przetwarzanie jest niezbędne ze względów związanych z interesem publicznym w dziedzinie zdrowia publicznego, jak np. ochrona przed poważnymi transgranicznymi zagrożeniami zdrowotnymi lub zapewnienie wysokich standardów jakości i bezpieczeństwa opieki zdrowotnej oraz produktów leczniczych lub wyrobów medycznych na podstawie prawa Unii lub prawa państwa członkowskiego, które przewidują odpowiednie, konkretne środki ochrony praw i wolności osób,

14 Rozporządzenie Parlamentu Europejskiego i Rady (UE) 2016/679 z dnia 27 kwietnia 2016 r. 
których dane dotyczą, w szczególności tajemnicę zawodową ${ }^{15}$. Analizując dane gromadzone w zakresie opieki farmaceutycznej i brak sprecyzowanych dokładnych ram prawnych tej opieki, należy uznać, że w przeważającej mierze apteki będą mogły w ramach świadczonej opieki farmaceutycznej przetwarzać dane wrażliwe wyłącznie za zgodą osób ich dotyczących.

Warto pochylić się nad formą omawianej zgody. Na gruncie wcześniej obowiązujących przepisów zgodnie z art. 7 pkt 5 ustawy o ochronie danych osobowych ${ }^{16}$ przez zgodę osoby, której dane dotyczą, rozumie się oświadczenie woli, którego treścią jest zgoda na przetwarzanie danych osobowych tego, kto składa oświadczenie, a zgoda ta nie może być domniemana lub dorozumiana $\mathrm{z}$ oświadczenia woli o innej treści. Wcześniej przez zgodę należało rozumieć tylko i wyłącznie oświadczenie woli i choć ustawa nie przewidywała określonej formy wskazanego oświadczenia (za wyjątkiem zgody na przetwarzanie danych o określonej specyfice, wskazanych w przedmiotowej ustawie), to musiała być ona wyraźna i odnosić się do przetwarzania określonych konkretnych danych osobowych - zgoda ta nie powinna bowiem mieć charakteru abstrakcyjnego i nie mogła dotyczyć przetwarzania danych osobowych w ogóle ${ }^{17}$. Na gruncie RODO definicja zgody na przetwarzanie danych osobowych ulega zmianie, ponieważ zgodnie z art. 4 pkt 11 zgoda osoby, której dane dotyczą, oznacza dobrowolne, konkretne, świadome i jednoznaczne okazanie woli, którym osoba, której dane dotyczą, w formie oświadczenia lub wyraźnego działania potwierdzającego pozwala na przetwarzanie dotyczących jej danych osobowych. Doszło więc do swoistej zamiany „oświadczenia woli” w tzw. okazanie woli, które może przyjąć formę oświadczenia lub wyraźnego działania potwierdzającego, na podstawie którego osoba, której dane dotyczą, pozwala na ich przetwarzanie. $Z$ całą pewnością wprowadzenie takiej definicji stanowi pewnego rodzaju złagodzenie dotychczasowych przepisów ${ }^{18}$. Analizując nowe przepisy, należy jednak podkreślić, że aby zgoda była w pełni skuteczna, osoba jej udzielająca musi przede wszystkim wiedzieć, na czyją rzecz udziela przedmiotowej zgody,

15 M. Kuba, Art. 9, [w:] RODO. Ogólne rozporządzenie o ochronie danych...

16 Ustawa z dnia 29 sierpnia 1997 r. o ochronie danych osobowych (t.j. Dz.U. z 2016 r., poz. 922 z późn. zm.).

17 P. Fajgielski, Art. 7, [w:] Komentarz do rozporządzenia nr 2016/679 w sprawie ochrony osób fizycznych w zwiazku z przetwarzaniem danych osobowych $i$ w sprawie swobodnego przeptywu takich danych oraz uchylenia dyrektywy 95/46/WE (ogólne rozporządzenie o ochronie danych), [w:] Ogólne rozporzadzenie o ochronie danych. Ustawa o ochronie danych osobowych. Komentarz, Warszawa 2018.

${ }_{18}$ H. Hoser, Zgoda na przetwarzanie danych w świetle przepisów Rozporządzenia Parlamentu Europejskiego i Rady (UE) 2016/679 z dnia 27 kwietnia 2016 roku w sprawie ochrony osób fizycznych $w$ zwiąku z przetwarzaniem danych osobowych $i$ w sprawie swobodnego przeplywu takich danych oraz uchylenia dyrektywy 95/46/WE. Jakie powinna spetniać warunki? Czy dotychczasowa zgoda zbierana na podstawie ustawy o ochronie danych osobowych jest zgodna z przepisami ogólnego rozporzadzenia o ochronie danych osobowych?, https://odoserwis.pl/a/1141/zgoda-na-przetwarzaniedanych-osobowych-wedlug-rodo [dostęp: 12.09.2018]. 
w jakim celu oraz posiadać wiedzę, jakie konkretnie dane mają być przetwarzane. Omawiana zgoda musi być dobrowolna, konkretna, świadoma i jednoznaczna. W piśmiennictwie szczególną uwagę zwraca się na kwestię dobrowolności w wyrażeniu takiej zgody. Wskazuje się, że za dobrowolną nie może być uznana zgoda w sytuacji, gdy od jej wyrażenia uzależnione jest wykonanie umowy, podczas gdy wyrażenie zgody nie posiada cechy niezbędności do jej wykonania, jak również za dobrowolną nie będzie traktowana zgoda, której nie można wyrazić w stosunku do poszczególnych operacji przetwarzania danych osobowych. W tym miejscu warto odnieść się do preambuły RODO, która niejako zawiera „podpowiedź” co do form wyrażenia zgody. Idąc za pkt 32 preambuły:

[...] wyrażenie zgody może polegać na zaznaczeniu okienka wyboru podczas przeglądania strony internetowej, na wyborze ustawień technicznych do korzystania z usług społeczeństwa informacyjnego lub też na innym oświadczeniu bądź zachowaniu, które w danym kontekście jasno wskazuje, że osoba, której dotyczą, zaakceptowała proponowane przetwarzanie jej danych osobowych.

W związku z faktem, że opieka farmaceutyczna może być świadczona w zakresie tzw. aptek internetowych, należy podkreślić, że za wyrażenie zgody nie można uznać milczenia czy okienek domyślnie zaznaczonych. Co istotne, zgodnie z zapisami preambuły zakres zgody powinien obejmować wszystkie czynności przetwarzania w tym samym celu lub w tych samych celach, a jeżeli przetwarzanie służy kilku celom, to zgoda musi obejmować je wszystkie ${ }^{19}$.

RODO nie przewiduje żadnej konkretnej formy sposobu wyrażenia zgody i dopuszcza jej wyrażenie także w formie ustnej. Trzeba jednak mieć na uwadze, że w sytuacji, gdy przetwarzanie odbywa się za zgodą, to na administratorze ciąży obowiązek wykazania, że osoba, której dane dotyczą, wyraziła zgodę na przetwarzanie swoich danych osobowych. Za najbezpieczniejsze - w szczególności w zakresie przetwarzania danych szczególnych, z czym mamy do czynienia przy świadczeniu opieki farmaceutycznej - będzie uznawane przyjęcie sposobu wyrażania zgody w formie możliwej do udokumentowania, a więc pisemnej lub za pomocą formularzy informatycznych.

Pod rozwagę należy poddać, czy dotychczas udzielane zgody na przetwarzanie danych osobowych (na gruncie ustawy o ochronie danych osobowych) pozostają w mocy. Zgodnie ze 171 motywem przetwarzanie, które w dniu wejścia w życie RODO już się toczy, powinno w terminie dwóch lat zostać dostosowane do nowych przepisów, a jeżeli postępowanie ma za podstawę zgodę, to osoba, której dane dotyczą, nie musi ponownie wyrażać zgody, jeżeli pierwotny sposób jej wyrażenia

19 A. Dmochowska, M. Zadrożny, Unijna reforma ochrony danych osobowych. Analiza zmian, Warszawa 2016, s. 19-20. 
odpowiada warunkom RODO. W związku z powyższym na podstawie uprzednio udzielonej zgody administrator może kontynuować przetwarzanie po wejściu w życie rozporządzenia pod warunkiem, że zgoda ta odpowiada rygorom zakreślonym w nowej regulacji. Analizując dotychczas udzielane zgody, największym problemem może okazać się brak informacji wymaganej przez RODO o możliwości wycofania takiej zgody w dowolnym momencie, co będzie prowadziło do konieczności uzyskania nowych zgód ${ }^{20}$. Poza powyższym wejście w życie RODO zasadniczo nie dokonało drastycznych zmian w warunkach udzielania zgody. Zmianie uległ jedynie charakter prawny zgody w stosunku do dotychczasowego stanu prawnego. Od momentu wejścia w życie RODO zwykła zgoda została zastąpiona przez tzw. zgodę jednoznaczną - oświadczenie woli musi być więc jednoznaczne, niepozwalające na wywołanie po stronie osoby udzielającej zgody jakichkolwiek wątpliwości. Co istotne, zmianie uległ również obowiązek uzyskania zgody na przetwarzanie danych szczególnych (dawniej wrażliwych) w formie pisemnej, ponieważ przepisy RODO nie nakładają - w przeciwieństwie do dotychczasowych - takiego wymogu. Wobec pewnego ,poluzowania” charakteru prawnego zgód można postawić tezę, że większość wyrażonych do tej pory zgód na przetwarzanie danych osobowych zachowuje swoją ważność pod rządami RODO ${ }^{21}$.

\section{DANE OSOBOWE PRZETWARZANE PRZEZ APTEKI W ZWIĄZKU Z WYDAWANIEM LEKÓW NA RECEPTĘ}

Do głównych zadań apteki należy wydawanie produktów leczniczych i wyrobów medycznych. Produkty lecznicze, wyroby medyczne i środki spożywcze specjalnego przeznaczenia żywieniowego wydawane są z apteki na podstawie recepty, bez recepty lub na podstawie zapotrzebowania podmiotu wykonującego działalność leczniczą. W związku z wejściem w życie RODO warto pochylić się nad danymi osobowymi znajdującymi się na receptach oraz nad problematyką ich przetwarzania. Zgodnie z art. 96a ustawy Prawo farmaceutyczne na recepcie powinny znajdować się przede wszystkim takie dane, jak: imię i nazwisko pacjenta, adres jego zamieszkania, data urodzin pacjenta/PESEL, dane osoby, która wystawiła receptę, w szczególności jej imię i nazwisko, kwalifikacje zawodowe, identyfikator pracownika medycznego i numer telefonu do wskazanej osoby, a ponadto dane dotyczące przepisanego produktu leczniczego, środka spożywczego specjalnego przeznaczenia lub wyrobu medycznego i inne. Apteka realizująca sprzedaż produk-

20 R. Rozwadowski, Potrzebne będa nowe zgody na przetwarzanie danych?, www.lex.pl/czytaj/-/ artykul/potrzebne-beda-nowe-zgody-na-przetwarzanie-danych [dostęp: 1.09.2018].

21 P. Makowski, Czy jesteś gotowy na RODO? Zgoda na przetwarzanie danych osobowych, https://giodo.gov.pl/pl/1520281/10014 [dostęp: 1.09.2018]. 
tów na recepty podlega reżimowi ustawy z dnia 12 maja 2011 r. o refundacji leków, środków spożywczych specjalnego przeznaczenia żywieniowego oraz wyrobów medycznych ${ }^{22}$. Zgodnie z art. 43 ust. 1 pkt 2 tej ustawy apteka ma obowiązek gromadzić i przekazywać Funduszowi rzetelne i zgodne ze stanem faktycznym na dzień przekazania informacje zawarte $\mathrm{w}$ treści poszczególnych zrealizowanych recept na refundowane leki, środki spożywcze specjalnego przeznaczenia żywieniowego, wyroby medyczne, a ponadto zgodnie z pkt 7 przywołanego powyżej przepisu musi przechowywać recepty na refundowane leki, środki spożywcze specjalnego przeznaczenia żywieniowego i wyroby medyczne wraz z otaksowaniem przez okres 5 lat, liczony od zakończenia roku kalendarzowego, w którym nastąpiła refundacja. Zgodnie z rozporządzeniem Ministra Zdrowia w sprawie recept ${ }^{23}$ recepty oraz dokumenty realizacji recept przetwarzane są w sposób zapewniający ich bezpieczeństwo i dostępność dla pacjenta, dla którego receptę wystawiono, osoby wystawiającej receptę, uprawnionych pracowników NFZ oraz organów Państwowej Inspekcji Farmaceutycznej w zakresie ich uprawnień. Wskazane dane są gromadzone i przechowywane w formie elektronicznej oraz przekazywane w formie komunikatów elektronicznych oddziałowi wojewódzkiemu Funduszu, właściwemu ze względu na siedzibę apteki.

Zgodnie z art. 6 ust. 1 lit. C RODO przetwarzanie danych osobowych jest zgodne z prawem, gdy jest ono niezbędne do wypełnienia obowiązku prawnego ciążącego na administratorze. W piśmiennictwie podkreśla się, że art. 6 ust. 1 lit. C RODO samodzielnie nie stanowi podstawy legalizacyjnej, a jedynie w połączeniu z obowiązującym przepisem prawa obowiązującym w państwie, któremu podlega administrator, ewentualnie w połączeniu $\mathrm{z}$ odpowiednim przepisem unijnym. Ponadto bardzo dużo uwagi zwraca się na przesłankę niezbędności przetwarzania tego typu danych ${ }^{24}$. Przenosząc powyższe na kwestie danych znajdujących się na realizowanych receptach, oczywiste jest, że istnieje obowiązek prawny ich przetwarzania legitymizujący powyższe działania. Nie można jednak zapominać, że oprócz standardowych danych osobowych recepty zawierają dane szczególne dotyczące stanu zdrowia określonej osoby. Dla zgodności z prawem przetwarzania wskazanych danych nie wystarczy sam obowiązek prawny ciążący na administratorze, ale musi zostać ziszczona także jedna z przesłanek wskazanych w art. 9 ust. 2 RODO. Zgodnie ze wskazanym przepisem dopuszczalne jest przetwarzanie danych szczególnych, jeżeli jest ono niezbędne ze względów związanych z interesem publicznym w dziedzinie zdrowia publicznego, takich jak ochrona przed poważnymi transgranicznymi zagrożeniami zdrowotnymi lub zapewnienie wysokich standardów jakości i bezpieczeństwa opieki zdrowotnej oraz produktów leczniczych lub wyrobów

22 Dz.U. z 2017 r., poz. 1844 z późn. zm.

23 Rozporządzenie Ministra Zdrowia z dnia 13 kwietnia 2018 r. w sprawie recept (Dz.U. poz. 745).

24 D. Lubasz, W. Chomiczewski, Art. 6, [w:] RODO. Ogólne rozporządzenie o ochronie danych... 
medycznych, na podstawie prawa Unii lub prawa państwa członkowskiego, które przewidują odpowiednie, konkretne środki ochrony praw i wolności osób, których dane dotyczą, w szczególności tajemnicę zawodową. Apteka przetwarza dane dotyczące zdrowia w celu leczenia pacjenta, jak również dla zapewnienia wysokich standardów jakości i bezpieczeństwa produktów leczniczych. Ponadto, zgodnie z obowiązującymi przepisami, członkowie samorządu aptekarskiego, a więc farmaceuci wykonujący zawód, są obowiązani zachować w tajemnicy wiadomości dotyczące zdrowia pacjenta uzyskane w związku z wykonywaniem zawodu (art. 21 pkt 2 ustawy z dnia 19 kwietnia 1991 r. o izbach aptekarskich) ${ }^{25}$. Bez wątpienia zatem przetwarzanie danych wrażliwych znajdujących się na receptach przez apteki jest jak najbardziej dopuszczalne na gruncie obowiązujących przepisów RODO.

Analizując dane przetwarzane przez apteki w związku z realizacją recept, nie sposób nie odnieść się do ciążącego od momentu wejścia w życie RODO obowiązku informacyjnego. Zgodnie z art. 13 RODO administrator danych, pozyskując dane od określonej osoby, musi udzielić jej szeregu informacji, jak m.in. jego tożsamość i dane kontaktowe, cel przetwarzania danych osobowych, informacje o odbiorcach danych osobowych, okres, przez który dane osobowe będą przechowywane i wielu innych. Przedmiotowe informacje powinny zostać przekazane w sposób zwięzły, przejrzysty i prostym językiem podczas pozyskiwania danych osobowych ${ }^{26}$. Przekazywanie tych informacji każdemu pacjentowi realizującemu receptę (biorąc pod uwagę w szczególności skalę powyższej sprzedaży oraz możliwość dokonywania przez pacjentów zakupu w różnych placówkach i brak ich przywiązania do jednej apteki) może nastręczać szereg trudności. W związku z tym warto odpowiedzieć sobie na pytanie, czy rzeczywiście zachodzi konieczność realizowania obowiązku informacyjnego względem pacjentów poprzez indywidualne przekazywanie im wskazanych informacji. Wydaje się, że nie - wystarczające będzie umieszczenie w widocznym miejscu odpowiedniej informacji spełniającej nałożony na administratora obowiązek informacyjny, tym bardziej że dla przetwarzania danych znajdujących się na receptach nie jest wymagana zgoda osoby, której dotyczą.

W zakresie realizacji obowiązku informacyjnego problematyczny jest brak jakiegokolwiek przepisu nakazującego zakup leków na receptę przez osobę, na którą została ona wystawiona. Powszechną praktyką jest realizacja recept $\mathrm{w}$ aptece przez członków rodziny czy znajomych pacjenta. Kuriozalne byłoby ograniczenie powyższej praktyki przez jakikolwiek przepis prawny, prowadziłoby to bowiem do

25 Dz.U. z 2016 r., poz. 1496; K. Baka, Przepisy Ogólnego rozporządzenia o ochronie danych (RODO) a obowiazki aptek ogólnodostępnych w zakresie przetwarzania danych osobowych - wybrane zagadnienia, www.loia.pl/news/2191/przepisy-ogolnego-rozporzadzenia-o-ochronie-danych.html [dostęp: 19.09.2018].

26 Realizacja praw osób, których dane dotycza, na podstawie RODO, red. B. Fischer, M. Sakowska-Baryła, Wrocław 2017, s. 97. 
krzywdzącego ograniczenia dostępu do produktów leczniczych. Również kwestia udzielania ewentualnych upoważnień osobom realizującym receptę w imieniu osoby trzeciej stanowiłaby nadmierną formalizację. W rzeczywistości administrator uzyskuje dane osobowe w inny sposób niż od osoby, której one dotyczą. Zgodnie z przepisami RODO administrator danych w takiej sytuacji jest zobowiązany dopełnić obowiązku informacyjnego $\mathrm{w}$ terminie jednego miesiąca po uzyskaniu danych osobowych, a w sytuacji, gdy wskazane dane mają być stosowane do komunikacji z daną osobą, obowiązek informacyjny powinien zostać spełniony najpóźniej przy pierwszej komunikacji z osobą, której dane dotyczą 27 . Taki obowiązek w zakresie realizacji recept przez inne osoby będzie niezwykle utrudniony, a w wielu przypadkach nawet niemożliwy - należy mieć na względzie, że osoba wydająca w aptece leki na receptę nie ma obowiązku ani możliwości wylegitymowania osoby realizującej receptę, w zasadzie swoje przekonanie o tym, że mamy do czynienia z inną osobą niż ta, na którą recepta została wystawiona, może opierać się tylko na kryteriach typu płeć i wiek (w przypadku zaistnienia dużej różnicy wieku pomiędzy podmiotem realizującym a tym, na którego została wystawiona recepta, jest on możliwy do ustalenia naocznie).

RODO w art. 14 ust. 5 przewiduje wypadki zwolnienia administratora $\mathrm{z}$ obowiązku informacyjnego. Takie zwolnienie nastąpi m.in. w sytuacji, gdy realizacja obowiązku informacyjnego jest niemożliwa lub wymaga niewspółmiernie dużego wysiłku, a pozyskiwanie lub ujawnienie danych jest wyraźnie uregulowane prawem Unii lub prawem państwa członkowskiego, któremu podlega administrator, przewidującym odpowiednie środki chroniące prawnie uzasadnione interesy osoby, której dane dotyczą, dane osobowe muszą pozostać poufne zgodnie z obowiązkiem zachowania tajemnicy zawodowej przewidzianym w prawie Unii lub $\mathrm{w}$ prawie państwa członkowskiego, w tym ustawowym obowiązkiem zachowania tajemnicy. Zdaje się, że wskazane powyżej przesłanki zwalniające z obowiązku informacyjnego znajdują oparcie w omawianej problematyce. Pozyskiwanie przedmiotowych danych zostało wyraźnie wskazane w ustawodawstwie polskim, a osoby je pozyskujące są objęte tajemnicą zawodową ${ }^{28}$. Oczywiste jest, że wymienione w art. 14 przesłanki zwalniające opierają się głównie na zwrotach niedookreślonych i dopiero określony czas obowiązywania RODO oraz opartych na nim decyzji da odpowiedź odnośnie do ich prawidłowej wykładni. W tym miejscu warto wskazać, że zgodnie z poradnikiem dotyczącym RODO, znajdującym się na stronie Naczelnej Izby Aptekarskiej, zalecane jest umieszczanie w dostępnym miejscu (analogicznie jak w przypadku informacji dla osoby, od której dane są pobierane) informacji zawierającej dane sprecyzowane w ogólnym rozporządzeniu dla osób, których dane są

27 A. Dmochowska, M. Zadrożny, op. cit., s. 26.

28 J. Łuczak, Art. 14, [w:] RODO. Ogólne rozporządzenie o ochronie danych... 
przetwarzane, a zostały uzyskane od innej osoby ${ }^{29}$. Choć w powyższym rozwiązaniu widoczny jest szereg mankamentów, to kierując się regułą wysokiej ostrożności, jest ono jak najbardziej zalecane.

\section{DANE OSOBOWE PRZETWARZANE W APTEKACH INTERNETOWYCH W ZWIĄZKU ZE SPRZEDAŻĄ WYSYŁKOWĄ LEKÓW WYDAWANYCH BEZ RECEPTY}

Na koniec warto odnieść się do problematyki aptek internetowych, popularnie zwanych także e-aptekami. Powyższe określenia odnoszą się do aptek i punktów aptecznych, które prowadzą sprzedaż wysyłkową leków dostępnych bez recepty oraz innych produktów, których dystrybucję może prowadzić apteka lub punkt apteczny. Należy podkreślić, że obecnie na gruncie ustawodawstwa polskiego nie jest dopuszczalna sprzedaż leków na receptę za pośrednictwem internetu. Sprzedaż wysyłkowa leków może być prowadzona tylko przez apteki i punkty apteczne. W związku z faktem, że apteki zobowiązane są m.in. do wydawania leków na receptę oraz do posiadania asortymentu pozwalającego na zaspokojenie potrzeb zdrowotnych miejscowej ludności, obecnie nie jest możliwe ograniczenie formy działalności aptek wyłącznie do sprzedaży wysyłkowej leków dostępnych bez recepty. Sprzedaż wysyłkowa stanowić będzie dodatkową sferę działalności apteki stacjonarnej, a nie główny i jedyny przedmiot jej działalności. Prowadzenie apteki internetowej obwarowane jest licznymi wymogami określonymi zarówno w przepisach rangi ustawowej, jak i podustawowej. Wymogi te regulują również zakres danych gromadzonych i przetwarzanych przez apteki prowadzące sprzedaż wysyłkową w związku z tą działalnością, jak również zasady i czas przechowywania wskazanych danych. Zakres danych gromadzonych przez apteki w związku z realizacją sprzedaży wysyłkowej określa art. 68 ust. 3G Prawa farmaceutycznego, który nakazuje prowadzić ewidencję produktów leczniczych sprzedawanych w drodze wysyłkowej, zawierającą: datę złożenia zamówienia, imię i nazwisko osoby składającej zamówienie, nazwę, serię i ilość produktów leczniczych, adres wysyłki oraz datę realizacji zamówienia. Powyższy obowiązek został doprecyzowany w rozporządzeniu Ministra Zdrowia z dnia 26 marca 2015 r. w sprawie wysyłkowej sprzedaży produktów leczniczych ${ }^{30}$, zgodnie z którym formularz zamówienia produktów leczniczych powinien zawierać m.in. takie dane, jak: imię, nazwisko i adres zamawiającego, adres poczty elektronicznej czy numer telefonu

29 K. Baka, E. Waniewska, P. Kucharczyk, RODO w twojej aptece - bezpłatny poradnik, instrukcja i dokumenty do pobrania, www.nia.org.pl/2018/05/24/rodo-w-twojej-aptece-poradnik -prawny-dotyczacy-stosowania-w-aptece-przepisow-rodo [dostęp: 13.09.2018].

30 Dz.U. poz. 481. 
zamawiającego. Ponadto, jeżeli produkt ma zostać odebrany przez inną osobę niż zamawiający, konieczne jest podanie danych tej osoby (imię i nazwisko, adres oraz numer telefonu komórkowego). Formularz zamówienia powinien zawierać również dane dotyczące produktu leczniczego, tj. jego nazwę, dawkę, wielkość opakowania, postać farmaceutyczną czy liczbę opakowań. Apteka prowadząca sprzedaż wysyłkową leków zobowiązana jest prowadzić ewidencję zamówień produktów leczniczych sprzedanych w drodze wysyłkowej, która powinna zawierać: datę złożenia zamówienia, imię i nazwisko osoby składającej zamówienie, nazwę, serię i ilość produktów leczniczych oraz adres wysyłki i datę realizacji zamówienia. Wskazana ewidencja musi być przechowywana przez okres co najmniej trzech lat od zakończenia roku kalendarzowego, w którym zrealizowano zamówienie.

Nie ulega wątpliwości, że wskazane powyżej dane należą do kategorii szczególnych danych osobowych, dostarczają bowiem informacji o stanie zdrowia konkretnej osoby. W związku w zasadzie z analogiczną sytuacją, jak w przypadku danych pozyskiwanych przez apteki wraz z realizacją recept, zgoda na ich przetwarzanie co do zasady nie powinna być wymagana. Na marginesie należy jednak zwrócić uwagę na fakt, że nabywanie leków dostępnych bez recepty w aptece stacjonarnej nie wiąże się z koniecznością zbierania przez aptekę jakichkolwiek danych osobowych. Osoba wydająca lek dostępny bez recepty nie prosi o podanie imienia i nazwiska kupującego czy jego numeru telefonu. Nie ma więc możliwości nie tylko niezwłocznego skontaktowania się z takim pacjentem w przypadku np. wycofania produktu leczniczego z obrotu, ale nawet ustalenia jego tożsamości. Warto zastanowić się nad tym, czy powyższe gromadzenie danych może rzeczywiście odbywać się bez zgody osoby, której one dotyczą. W przypadku przetwarzania danych wrażliwych sam przepis prawny nakazujący administratorowi gromadzenie określonych danych nie stanowi samoistnej przesłanki pozwalającej na ich przetwarzanie. Musi ono być uzasadnione m.in. interesem publicznym $\mathrm{w}$ dziedzinie zdrowia publicznego czy koniecznością zapewnienia wysokich standardów i bezpieczeństwa produktów leczniczych. Należy odpowiedzieć sobie na pytanie, czy powyższe cele nie mogą zostać osiągnięte bez gromadzenia danych osobowych we wskazanym powyżej zakresie, tym bardziej że obrót produktami leczniczymi wydawanymi bez recepty w aptekach stacjonarnych nie wymaga pozyskiwania wskazanych danych. $\mathrm{Z}$ tego względu warto rozważyć, czy pomimo wyraźnego obowiązku prawnego nałożonego na apteki internetowe do przetwarzania wskazanych danych szczególnych dotyczących zdrowia spełnione są przesłanki wskazane w art. 9 ust. 2, a co za tym idzie dozwolone jest ich przetwarzanie bez zgody pacjenta. Choć pozyskiwaniu i przechowywaniu powyższych danych mogą towarzyszyć takie cele, jak zapewnienie wysokich standardów i bezpieczeństwa produktów leczniczych, to nie ulega wątpliwości, że w kontekście procedury obowiązującej przy sprzedaży stacjonarnej takie założenie może okazać się niewystarczające. Wydaje się, że z daleko 
posuniętej ostrożności zasadne byłoby uzyskanie od klientów apteki internetowej zgody na przetwarzanie tego typu danych i stworzenie w ten sposób alternatywnej przesłanki legitymizującej wskazane czynności.

\section{PODSUMOWANIE}

Jak zostało wskazane we wstępie, RODO wyznacza cel, który powinni osiągnąć przedsiębiorcy, nie wskazując jednak dokładnej drogi. Takie rozwiązanie w początkowej fazie obowiązywania rozporządzenia nastręcza szereg trudności w zakresie wykładni poszczególnych przepisów.

Działalność aptek nierozerwalnie jest związana z pozyskiwaniem danych dotyczących zdrowia. RODO powyższe dane klasyfikuje jako dane szczególne, których przetwarzanie może nastąpić jedynie w przypadkach wskazanych w rozporządzeniu. Jak podkreślono, dane dotyczące zdrowia przetwarzane przez apteki nie mogą zostać wrzucone do ,jednego worka" - każdorazowo należy rozważyć, na jakiej podstawie ich przetwarzanie jest dopuszczalne. Niniejsze opracowanie ukazuje jedynie niewielki wycinek problematyki dotyczącej wdrożenia RODO w aptekach ogólnodostępnych.

\section{BIBLIOGRAFIA}

Baka K., Przepisy Ogólnego rozporządzenia o ochronie danych (RODO) a obowiąki aptek ogólnodostepnych $w$ zakresie przetwarzania danych osobowych - wybrane zagadnienia, www.loia.pl/ news/2191/przepisy-ogolnego-rozporzadzenia-o-ochronie-danych.html [dostęp: 19.09.2018].

Baka K., Waniewska E., Kucharczyk P., RODO w twojej aptece - bezpłatny poradnik, instrukcja $i$ dokumenty do pobrania, www.nia.org.pl/2018/05/24/rodo-w-twojej-aptece-poradnik-prawny -dotyczacy-stosowania-w-aptece-przepisow-rodo [dostęp: 13.09.2018].

Bielak-Jomaa E., Lubasz D., Stowo wstępne, [w:] RODO. Ogólne rozporządzenie o ochronie danych. Komentarz, red. E. Bielak-Jomaa, D. Lubasz, Warszawa 2018.

Dmochowska A., Zadrożny M., Unijna reforma ochrony danych osobowych. Analiza zmian, Warszawa 2016.

Dyrektywa 95/46/WE Parlamentu Europejskiego i Rady z dnia 24 października 1995 r. w sprawie ochrony osób fizycznych w zakresie przetwarzania danych osobowych i swobodnego przepływu tych danych (Dz.Urz. UE L 281, 23.11.1995, P. 0031-0050).

Fajgielski P., Art. 7, [w:] Komentarz do rozporzadzenia nr 2016/679 w sprawie ochrony osób fizycznych w zwiazku z przetwarzaniem danych osobowych $i$ w sprawie swobodnego przeptywu takich danych oraz uchylenia dyrektywy 95/46/WE (ogólne rozporzadzenie o ochronie danych), [w:] Ogólne rozporzadzenie o ochronie danych. Ustawa o ochronie danych osobowych. Komentarz, Warszawa 2018.

Hoser H., Zgoda na przetwarzanie danych w świetle przepisów Rozporządzenia Parlamentu Europejskiego i Rady (UE) 2016/679 z dnia 27 kwietnia 2016 roku w sprawie ochrony osób fizycznych $w$ zwiazku z przetwarzaniem danych osobowych $i$ w sprawie swobodnego przeptywu takich da- 
nych oraz uchylenia dyrektywy 95/46/WE. Jakie powinna spetniać warunki? Czy dotychczasowa zgoda zbierana na podstawie ustawy o ochronie danych osobowych jest zgodna z przepisami ogólnego rozporządzenia o ochronie danych osobowych?, https://odoserwis.pl/a/1141/zgoda-na -przetwarzanie-danych-osobowych-wedlug-rodo [dostęp: 12.09.2018].

Komunikat Komisji do Parlamentu Europejskiego, Rady Europejskiej, Komitetu Ekonomiczno-Społecznego i Komitetu Regionów: Ochrona prywatności w połączonym świecie - europejskie ramy ochrony danych w XXI wieku, COM (2012) 9 final, s. 4 (EUR-Lex - 52012DC0009 - EN).

Kuba M., Art. 9, [w:] RODO. Ogólne rozporządzenie o ochronie danych. Komentarz, red. E. Bielak-Jomaa, D. Lubasz, Warszawa 2018.

Kwiatkowska M., Prawo farmaceutyczne dla aptek, cz. 1, Warszawa 2017.

Lubasz D., Chomiczewski W., Art. 6, [w:] RODO. Ogólne rozporządzenie o ochronie danych. Komentarz, red. E. Bielak-Jomaa, D. Lubasz, Warszawa 2018.

Lubasz D., Chomiczewski W., Czerniawski M., Drobek M., Góral U., Kuba M., Makowski P., Witkowska-Nowakowska K., Art. 4, [w:] RODO. Ogólne rozporządzenie o ochronie danych. Komentarz, red. E. Bielak-Jomaa, D. Lubasz, Warszawa 2018.

Łuczak J., Art. 14, [w:] RODO. Ogólne rozporządzenie o ochronie danych. Komentarz, red. E. Bielak-Jomaa, D. Lubasz, Warszawa 2018.

Makowski P., Czy jesteś gotowy na RODO? Zgoda na przetwarzanie danych osobowych, https:// giodo.gov.pl/p1/1520281/10014 [dostęp: 1.09.2018].

Masiakowski J., Farmaceuta kliniczny jako producent i dystrybutor leków oraz konsultant w zespole opieki nad chorym, [w:] Zarys farmacji klinicznej, red. L. Krówczyński, A. Danek, Warszawa 1988.

Meritum Prawo Farmaceutyczne, red. B. Wawrzyńczak-Jędryka, Warszawa 2016.

Ogiełł L., Prawo farmaceutyczne. Komentarz, Warszawa 2010.

Ogólne rozporzadzenie o ochronie danych osobowych. Wybrane zagadnienia, red. M. Kawecki, T. Osiej, Warszawa 2017.

Ożóg M., System handlu produktem leczniczym i produktami pokrewnymi. Problematyka prawna, Warszawa 2010.

Realizacja praw osób, których dane dotycza, na podstawie RODO, red. B. Fischer, M. Sakowska-Baryła, Wrocław 2017.

Rozporządzenie Ministra Zdrowia z dnia 26 marca 2015 r. w sprawie wysyłkowej sprzedaży produktów leczniczych (Dz.U. poz. 481).

Rozporządzenie Ministra Zdrowia z dnia 13 kwietnia 2018 r. w sprawie recept (Dz.U. poz. 745).

Rozporządzenie Parlamentu Europejskiego i Rady (UE) 2016/679 z dnia 27 kwietnia 2016 r. w sprawie ochrony osób fizycznych w związku z przetwarzaniem danych osobowych i w sprawie swobodnego przepływu takich danych oraz uchylenia dyrektywy 95/46/WE (ogólne rozporządzenie o ochronie danych) (Dz.Urz. UE L z 2016 r., nr 119, s. 1 z późn. zm.).

Rozwadowski R., Potrzebne będa nowe zgody na przetwarzanie danych?, www.lex.pl/czytaj/-/artykul/ potrzebne-beda-nowe-zgody-na-przetwarzanie-danych [dostęp: 1.09.2018].

Ustawa z dnia 23 kwietnia 1964 r. - Kodeks cywilny (Dz.U. z 2017 r., poz. 459 z późn. zm.).

Ustawa z dnia 19 kwietnia 1991 r. o izbach aptekarskich (Dz.U. z 2016 r., poz. 1496).

Ustawa z dnia 29 sierpnia 1997 r. o ochronie danych osobowych (t.j. Dz.U. z 2016 r., poz. 922 z późn. zm.).

Ustawa z dnia 6 września 2001 r. - Prawo farmaceutyczne (Dz.U. z 2017 r., poz. 2211).

Ustawa z dnia 12 maja 2011 r. o refundacji leków, środków spożywczych specjalnego przeznaczenia żywieniowego oraz wyrobów medycznych (Dz.U. z 2017 r., poz. 1844 z późn. zm.).

Wyrok NSA z dnia 27 sierpnia 2014 r., II GSK 1000/13, LEX nr 1527483. 
Pobrane z czasopisma Studenckie Zeszyty Naukowe http://szn.umcs.pl

Data: 26/04/2023 15:09:37

\section{SUMMARY}

This study focuses on the issue of personal data processing in a public pharmacy. Based on the regulations of the General Data Protection Regulation, the author analyzes the personal data processed by pharmacies. The analyzed material consists of personal data which processing is inherent to the activity of a pharmacy. The author concentrates especially on the sensitive personal data processed by the pharmacies, mainly in the context of acceptability of such processing.

Keywords: personal data; pharmacy law; pharmacy; GDPR; General Data Protection Regulation; special data; sensitive personal data 